\title{
In vitro evaluation of amino acid prodrugs of novel antitumour 2-(4-amino-3-methylphenyl)benzothiazoles
}

\author{
TD Bradshaw*,', M-S Chua', HL Browne', V Trapani', EA Sausville² and MFG Stevens' \\ 'Cancer Research Laboratories, School of Pharmaceutical Sciences, University of Nottingham, Nottingham NG7 2RD, UK; ${ }^{2}$ Developmental Therapeutics \\ Program, Division of Cancer Treatment and Diagnosis, National Cancer Institute, NIH, Frederick, Maryland, MD 21702-I20I, USA
}

Novel 2-(4-aminophenyl)benzothiazoles possess highly selective, potent antitumour properties in vitro and in vivo. They induce and are biotransformed by cytochrome P450 (CYP) IAI to putative active as well as inactive metabolites. Metabolic inactivation of the molecule has been thwarted by isosteric replacement of hydrogen with fluorine atoms at positions around the benzothiazole nucleus. The lipophilicity of these compounds presents limitations for drug formulation and bioavailability. To overcome this problem, water soluble prodrugs have been synthesised by conjugation of alanyl- and lysyl-amide hydrochloride salts to the exocyclic primary amine function of 2-(4-aminophenyl)benzothiazoles. The prodrugs retain selectivity with significant in vitro growth inhibitory potency against the same sensitive cell lines as their parent amine, but are inactive against cell lines inherently resistant to 2-(4-aminophenyl)benzothiazoles. Alanyl and lysyl prodrugs rapidly and quantitatively revert to their parent amine in sensitive and insensitive cell lines in vitro. Liberated parent compounds are sequestered and metabolised by sensitive cells only; similarly, CYPIAI activity and protein expression are selectively induced in sensitive carcinoma cells. Amino acid prodrugs meet the criteria of aqueous solubility, chemical stability and quantitative reversion to parent molecule, and thus are suitable for in vivo preclinical evaluation.

British Journal of Cancer (2002) 86, 1348- 1354. DOI: 10.1038/sj/bjc/6600225 www.bjcancer.com

(C) 2002 Cancer Research UK

Keywords: 2-(4-aminophenyl)benzothiazole; prodrug; CYPIAI

Novel 2-(4-aminophenyl)benzothiazoles possess remarkable and intriguing antitumour properties (Shi et al, 1996; Bradshaw et al, 1998a) representing a mechanistic class distinct from clinically used chemotherapeutic agents. Consistently, they are active against only a specific subset of human cancer cell lines in the National Cancer Institute (NCI) in vitro anticancer drug screen, producing mean graph patterns that are highly characteristic of this class of compounds only. Moreover, growth inhibition in vitro is characterised by a unique biphasic dose-response relationship (Bradshaw et al, 1998a,b). In vivo, 2-(4-amino-3-methylphenyl)benzothiazole compound 1 outperformed the $3^{\prime}$-halogeno counterparts in breast, colon and ovarian xenograft studies.

Compound 1 is efficiently sequestered by sensitive cell lines (e.g. breast MCF-7, MDA-468; renal TK-10) (Chua et al, 1999; Kashiyama et al, 1999). CYP1A1 mRNA (Hose et al, 2001; Monks et al, 2001) activity and protein expression (Chua et al, 2000) are induced exclusively in sensitive cell lines. Covalent binding, detected between compound $\mathbf{1}$ and recombinant CYP1A1, requires metabolism and is significantly reduced by glutathione (Chua et al, 2000). This suggests that an electrophilic, reactive intermediate species is formed. The $C-6$ oxidation biotransformation product, liberated into nutrient media, however, is devoid of antitumour activity (Kashiyama et al, 1999). Moreover, this metabolite antagonises cellular uptake of compound 1, covalent binding between CYP1A1 and compound 1, CYP1A1 activity and growth inhibition induced by compound 1 . In addition, hydroxy derivatives of

*Correspondence: TD Bradshaw; E-mail: rcztb@unix.nottingham.ac.uk Received 17 October 200I; revised 4 February 2002; accepted 5 February 2002 compound 1 possess mitogenic properties at $\mu \mathrm{M}$ concentrations (Hutchinson et al, 2001). In contrast, insensitive cell lines (e.g. breast MDA-MB-435; renal A498, CAKI-1; prostate PC-3) neither retain nor metabolise compound $\mathbf{1}$ (Kashiyama et al, 1999).

Fluorinated analogues of 2-(4-aminophenyl)benzothiazoles have been synthesised which successfully block $C$-oxidation (Hutchinson et al, 2001). 2-(4-Amino-3-methylphenyl)-5-fluorobenzothiazole (compound 2) is the favoured analogue for clinical consideration possessing enhanced efficacy in vitro and superior potency in vivo against human breast and ovarian tumour xenografts implanted in nude mice. 2-(4-Aminophenyl)benzothiazoles, which are synthetically accessible, small and lipophilic pose a pharmaceutical challenge, as aqueous i.v. formulations would be desired to minimise the possibility of first pass deactivating metabolism and improve drug bioavailability.

Amino acid conjugation may be utilised to enhance the aqueous solubility of amine or alcohol drugs (as amide or ester prodrugs respectively). The primary aromatic amine, dapsone, has been derivatised as amino acid amides fulfilling the criteria for a suitable prodrug-water solubility, chemical stability and rapid, quantitative bioreversion to the parent moiety (Pochopin et al, 1995). The exocyclic primary amine function of 2-(4amino-3-methylphenyl)benzothiazoles has been successfully conjugated to alanine and lysine residues as the mono- and dihydrochloride salts respectively (Hutchinson et al, 2002); such structural manipulation converts lipophilic benzothiazoles into water soluble prodrugs (Figure 1). Herein, reversion of prodrugs to parent molecule and selective antitumour activity in vitro has been described. In addition, we demonstrate that interaction with the putative molecular target of this class of agent, CYP1A1, has not been compromised. 


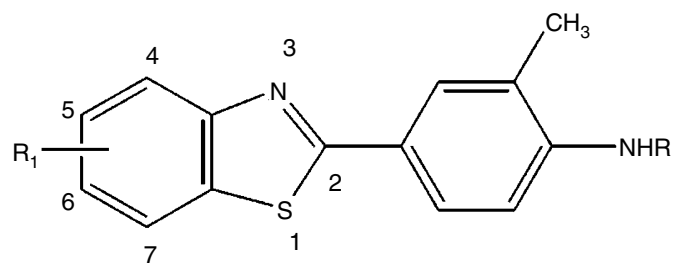

\begin{tabular}{|c|c|c|}
\hline Compound & $\mathrm{R}^{a}$ & $\mathrm{R}_{1}$ \\
\hline 1 & $\mathrm{H}$ & $\mathrm{H}$ \\
\hline $1 a$ & L-alanyl & $\mathrm{H}$ \\
\hline $1 b$ & L-lysyl & $\mathrm{H}$ \\
\hline 2 & $\mathrm{H}$ & $5-\mathrm{F}$ \\
\hline $2 a$ & L-alanyl & $5-\mathrm{F}$ \\
\hline $2 b$ & L-lysyl & $5-F$ \\
\hline 3 & $\mathrm{H}$ & $6-\mathrm{F}$ \\
\hline $3 a$ & L-alanyl & $6-\mathrm{F}$ \\
\hline $3 b$ & L-lysyl & $6-\mathrm{F}$ \\
\hline 4 & $\mathrm{H}$ & 5,6-di-F \\
\hline $4 a$ & L-alanyl & 5,6-di-F \\
\hline $4 b$ & L-lysyl & $5,6-\mathrm{di}-\mathrm{F}$ \\
\hline
\end{tabular}
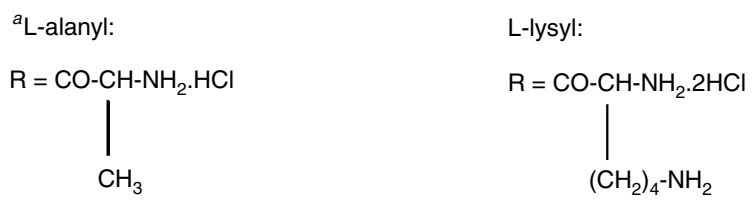

Figure I Structures of 2-(4-aminophenyl)benzothiazoles and their amino acid prodrugs.

\section{MATERIALS AND METHODS}

\section{Growth inhibitory assays}

Prodrugs were prepared as $10 \mathrm{mM}$ top stocks, dissolved in dimethylsulphoxide (DMSO) or sterile $\mathrm{ddH}_{2} \mathrm{O}$, and stored at $4{ }^{\circ} \mathrm{C}$, protected from light for a maximum period of 4 weeks. MCF-7 (ER+) and MDA 468 (ER-) human derived breast carcinoma cells, cultivated at $37^{\circ} \mathrm{C}$ in an atmosphere of $5 \% \mathrm{CO}_{2}$ in RPMI 1640 medium supplemented with $2 \mathrm{mM}$ L-glutamine and $10 \%$ foetal calf serum, were routinely subcultured twice weekly to maintain continuous logarithmic growth. Cells were seeded into 96-well microtiter plates at a density of $5 \times 10^{3}$ per well and allowed $24 \mathrm{~h}$ to adhere before drugs were introduced (final concentration $0.1 \mathrm{nM}-100 \mu \mathrm{M}, n=8$ ). Serial drug dilutions were prepared in medium immediately prior to each assay. Viable cell masses at the time of drug addition (time-zero), and following $72 \mathrm{~h}$ drug exposure were determined by cell-mediated 3-(4,5dimethylthiazol-2-yl)-2,5-diphenyltetrazolium bromide (MTT) reduction. MTT was added to each well (final concentration $400 \mu \mathrm{g} \mathrm{ml}^{-1}$ ) and plates were incubated at $37^{\circ} \mathrm{C}$ for $4 \mathrm{~h}$ to allow reduction of MTT by viable cell dehydrogenases to an insoluble formazan product. Well supernatants were aspirated and cellular formazan solubilised by addition of DMSO:glycine buffer $(\mathrm{pH} 10.5)(4: 1)$. Cell growth as well as drug activity were deter- mined by measuring absorbance at $550 \mathrm{~nm}$ using an Anthos Labtec systems plate reader.

\section{NCI in vitro cytotoxicity assays}

Cell culture and drug application procedures have been described previously (Boyd and Paull, 1995). Briefly, cell lines were inoculated into a series of 96-well microtiter plates, with varied seeding densities depending on growth characteristics of each cell line. Following a $24 \mathrm{~h}$ drug free incubation, test agents were added at five 10-fold dilutions with a maximum concentration of $100 \mu \mathrm{M}$. Cellular protein levels were determined after $48 \mathrm{~h}$ drug exposure by sulphorhodamine B colorimetry.

\section{Metabolism studies}

MCF-7 cells were seeded into $25 \mathrm{ml}$ flasks at appropriate densities $\left(5 \times 10^{5}-5 \times 10^{6}\right)$. After $24 \mathrm{~h}$, medium was changed and drug introduced at a final concentration of $10 \mu \mathrm{M}$. Media samples, collected from flasks at time zero and $24 \mathrm{~h}$ intervals, were mixed with 1.5-fold volumes of high performance liquid chromatography (HPLC) grade acetonitrile to precipitate protein and centrifuged at $14000 \mathrm{~g}$ for $5 \mathrm{~min}$. Supernatants $(600 \mu \mathrm{l})$ were mixed with $400 \mu \mathrm{l} 10 \%$ acetonitrile in $1 \%$ acetic acid and analysed by HPLC. The system consisted of Beckman System Gold equipment 
(solvent module 128, autosampler 507e and multiple wavelength UV detector 168). Separation of parent compounds and biotransformation products was effected at room temperature on a Phenomenex Aqua C18 reversed-phase column $(150 \times 4.6 \mathrm{~mm})$. The mobile phase was formed by increasing, then decreasing the acetonitrile concentration in $1 \%$ acetic acid over $20 \mathrm{~min}$ by mixing two solutions: acetonitrile-water-acetic acid (10:90:1, $\left.\mathrm{v} \mathrm{v}^{-1}\right)$ and acetonitrile-water-acetic acid $\left(80: 20: 1 \mathrm{v} \mathrm{v}^{-1}\right)$ and

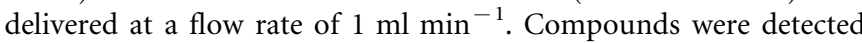
at $324 \mathrm{~nm}$.

\section{Western blot protocol}

Whole cell lysates were prepared for examination of CYP1A1 protein expression from untreated MCF-7, IGROV-1 and HCT 116 cultures and following exposure of cells to compounds 1, 2, 2a, 2b, 3, 3a, 3b, 4, 4a and 4b. Following protein determination ( $n=3$, Bradford, 1976) and addition of sample buffer,

A

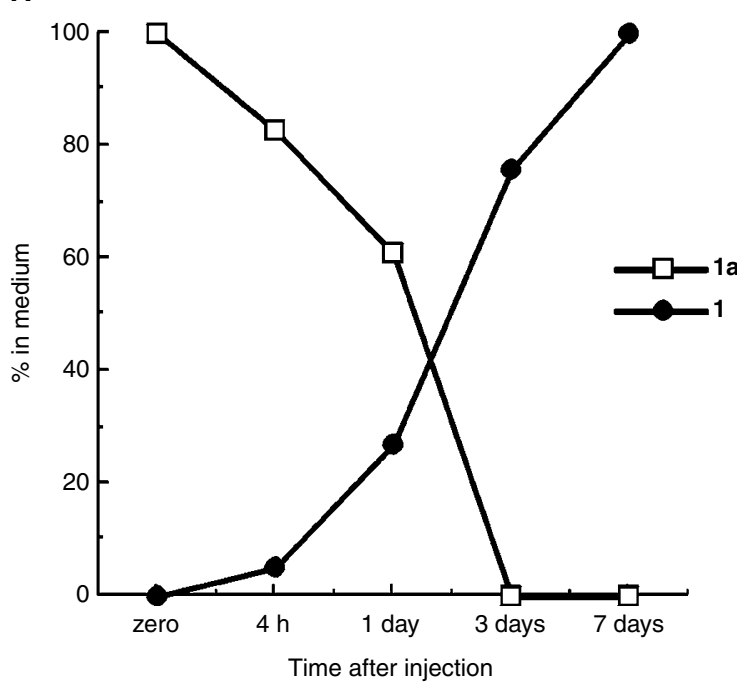

B

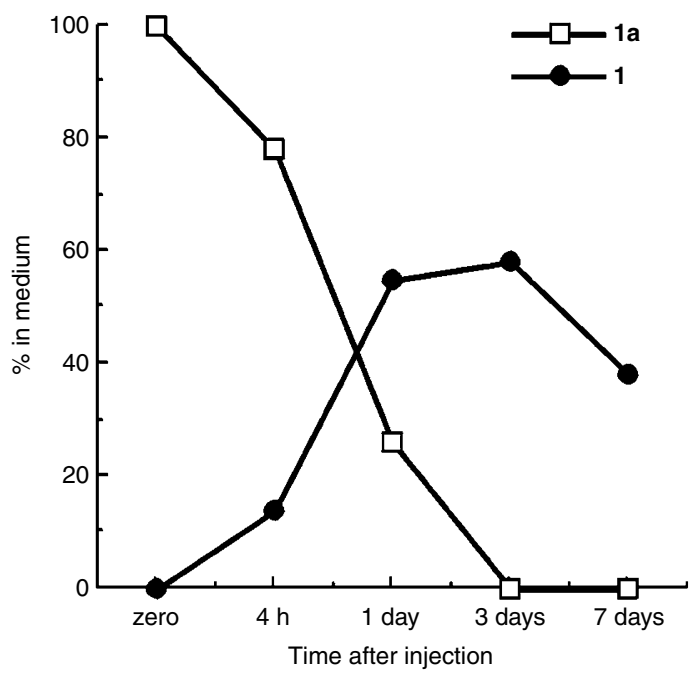

Figure 2 Uptake and conversion of $10 \mu \mathrm{M}$ compounds Ia to $\mathbf{I}$ in: $(\mathbf{A})$ inherently insensitive A498 renal cells and (B) sensitive ER+ T47D breast cells. Compound $\mathbf{I} \mathbf{a}$ is rapidly and efficiently hydrolysed by both cell lines. Only sensitive cells (B) sequester regenerated compound $\mathbf{I}$. samples were boiled at $95^{\circ} \mathrm{C}$ for $5 \mathrm{~min}$ and solubilised proteins $(50 \mu \mathrm{g})$ were separated by sodium dodecyl sulphate (SDS) polyacrylamide gel (10\%) electrophoresis. Proteins were electroblotted to polyvinylidene difluoride (PVDF) membranes and probed for CYP1A1 protein with polyclonal antiserum specific for human CYP1A1/1A2 (Gentest Corporation). Secondary antibody was conjugated to alkaline phosphatase, and CYP1A1 was detected following brief $(<10 \mathrm{~min})$ incubation with bromochloroindolyl phosphate and nitro-blue tetrazolium in alkaline phosphatase buffer. Molecular weight markers and a positive control of recombinant CYP1A1 (Gentest Corporation), included in all blots, confirmed detection of $52 \mathrm{kDa}$ CYP1A1 protein.

A

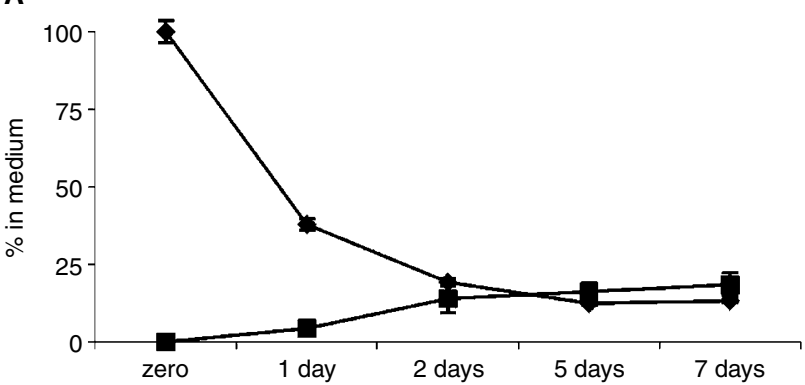

B

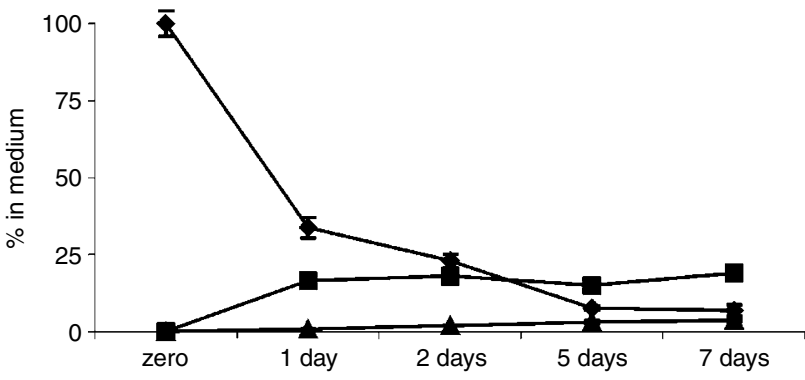

C

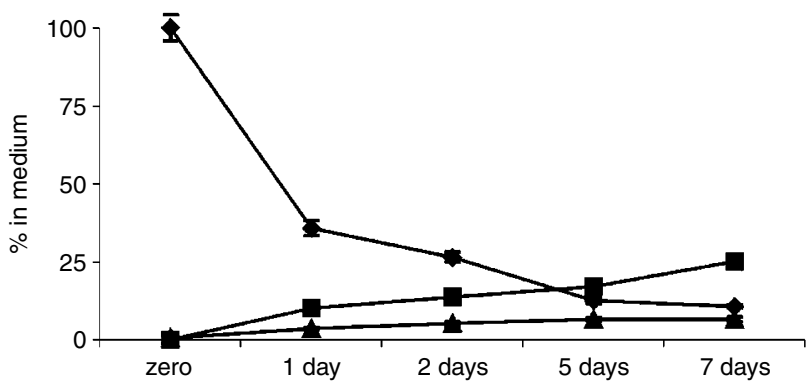

Figure 3 Depletion of $(\mathbf{A})$ compound $\mathbf{2 a}$, (B) compound $\mathbf{3 a}$ and $(\mathbf{C})$ compound $\mathbf{4 a}(10 \mu \mathrm{M})$ from nutrient media supporting MCF-7 growth, conversion of prodrugs to the corresponding parent amine and further metabolism of compounds $\mathbf{3}$ and $\mathbf{4}$ only by MCF-7 cells (B and $\mathbf{C}$ ). 
Determination of ethoxyresorufin $\mathrm{O}$-deethylase (EROD activity)

A sensitive and rapid fluorometric assay was used to measure EROD activity (Burke et al, 1994). Incubation mixtures (total $1 \mathrm{ml}$ ) consisted of $100 \mathrm{mM}$ Tris-HCl (pH 7.4), $50 \mu \mathrm{M} \mathrm{MgCl}_{2}$, $100 \mu \mathrm{M}$ 7-ethoxyresorufin and $100 \mu \mathrm{l}$ cell homogenate. Homogenates were prepared following treatment of cells for $24 \mathrm{~h}$ with compounds $1,2,2 \mathbf{a}, 2 \mathbf{b}, \mathbf{3}, \mathbf{3} \mathbf{a}, \mathbf{3} \mathbf{b}, \mathbf{4}, \mathbf{4} \mathbf{a}$ and $\mathbf{4 b}$ or vehicle alone and protein content determined $(n=3)$. Thus induction of ethoxy-resorufin $\mathrm{O}$-deethylation by agents under study, catalysed by CYP1A1 activity, could be determined. Alternatively, microsomes expressing recombinant CYP1A1 $\left(0.1 \mathrm{mg} \mathrm{ml}^{-1}\right)$ provided the enzyme source for EROD catalysis, in the presence or absence of drug, in order to determine inhibition of CYP1A1 activity by compounds 1, 2, 2a, 2b, 3, 3a, 3b, 4, 4a and 4b. Incubation mixtures were pre-incubated for $5 \mathrm{~min}$ at $37^{\circ} \mathrm{C}$ before initiation of reaction by addition of NADPH $(500 \mu \mathrm{M})$. Following further incubations at $37^{\circ} \mathrm{C}(30 \mathrm{~min}$ for cell homogenates, $15 \mathrm{~min}$ for CYP1A1 microsomes), reactions were terminated by addition of

A

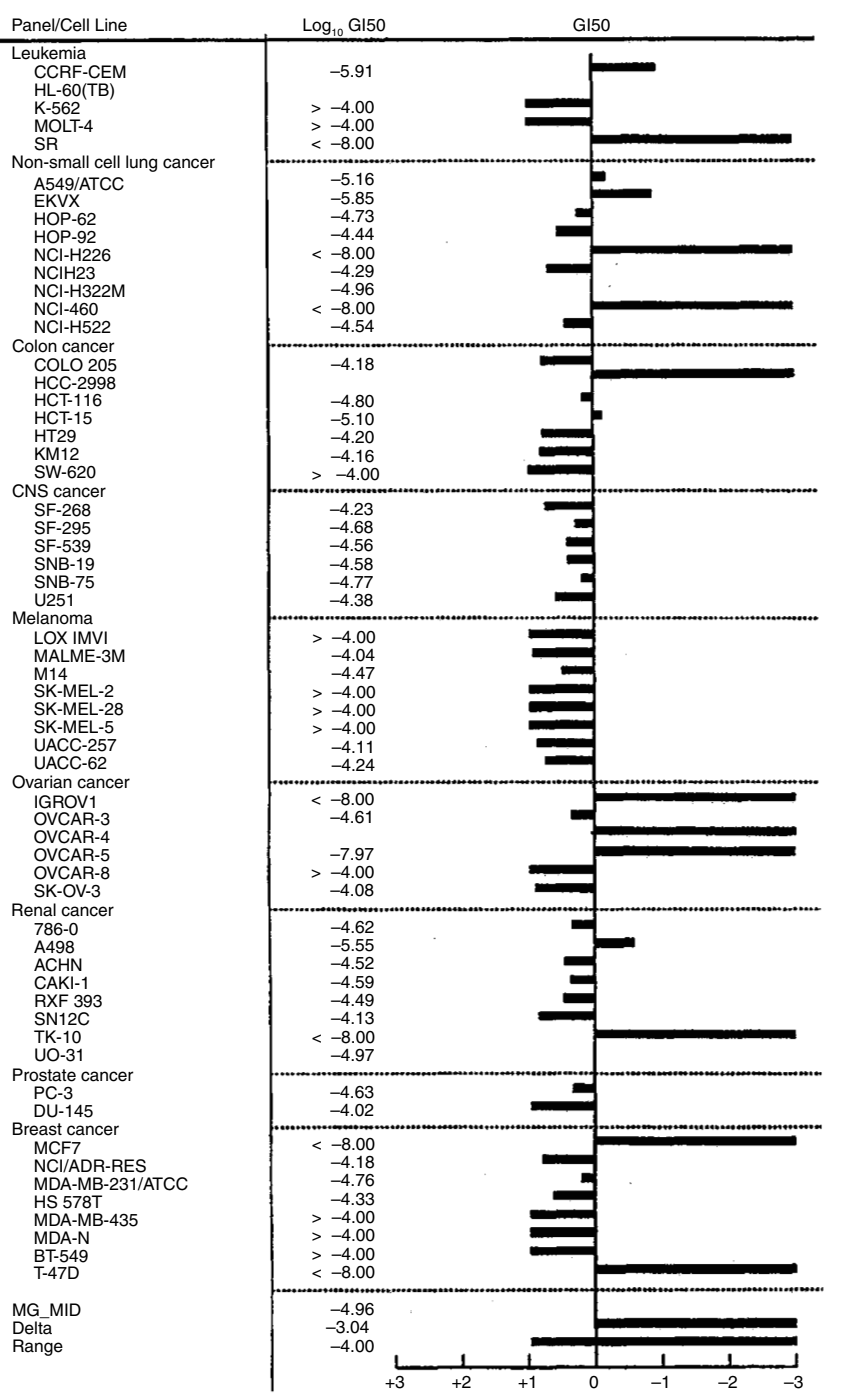

$3 \mathrm{ml}$ ice-cold acetonitrile. Reaction mixtures were centrifuged (1400 r.p.m., $10 \mathrm{~min}$ ) before analyses of supernatants. Fluorescence was read on a Perkin-Elmer LS-5 luminescence spectrometer (excitation, $530 \mathrm{~nm}$; emission $585 \mathrm{~nm}$ ). Estimation of resorufin reaction product (pmoles $\mathrm{mg}^{-1}$ protein, pmoles $100 \mu \mathrm{g}^{-1}$ microsomes), as a measure of CYP1A1 activity, was determined following performance of a resorufin standard curve.

\section{RESULTS}

\section{Prodrug uptake and conversion to parent amine}

Uptake and metabolism of compounds $\mathbf{1 a}$ and $\mathbf{1 b}$ were examined in sensitive breast (MCF-7 and T47D) and insensitive renal (A498) cells using HPLC conditions which allow simultaneous detection of prodrug, parent amine and metabolites. When incubated at $0.1,1$ or $10 \mu \mathrm{M}$ over 7 days at $37^{\circ} \mathrm{C}$, the lysyl-amide compound 1a was most readily removed from the media supporting MCF-7 and T47D cells (Figure 2). The decline of each prodrug in media was accompanied by the appearance of compound $\mathbf{1}$.
B

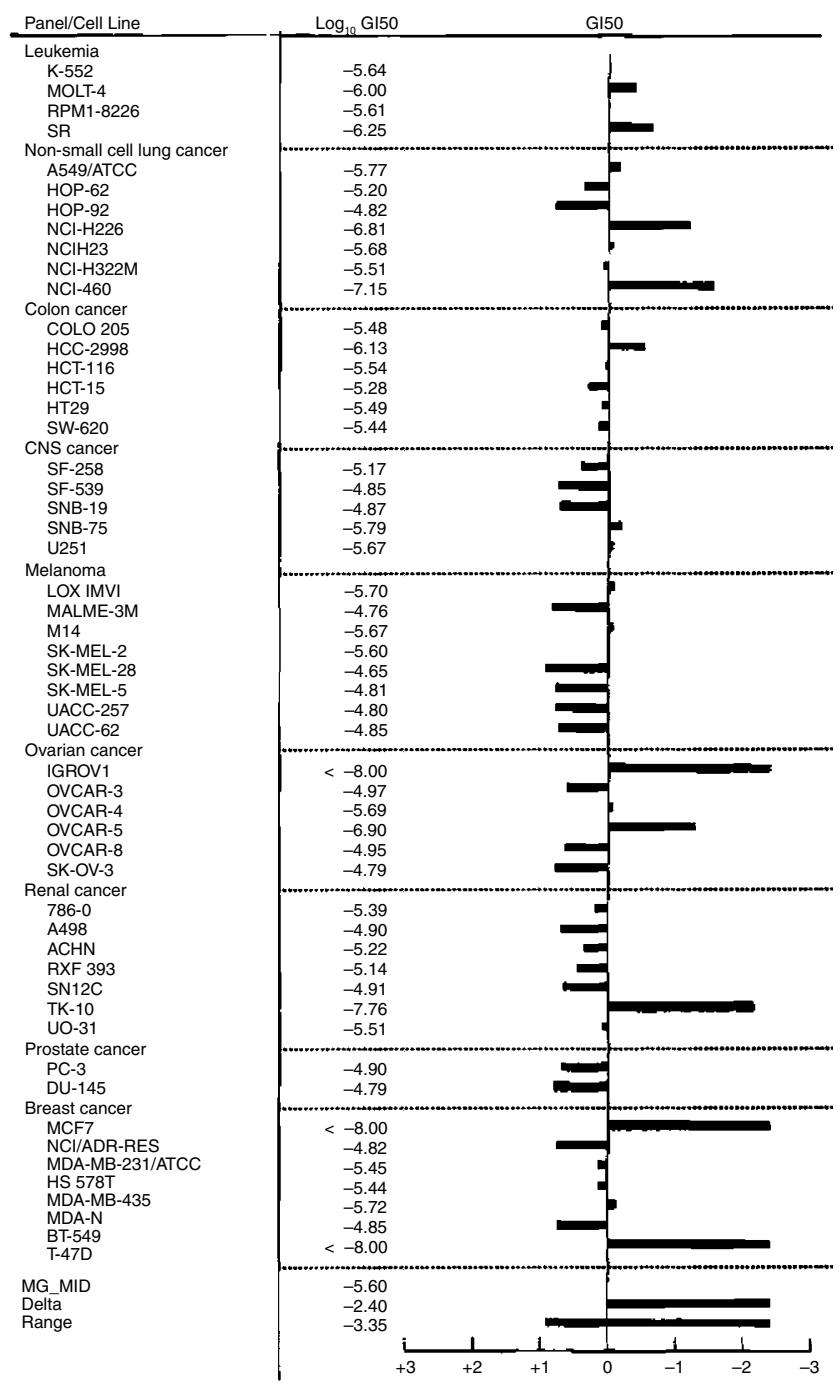

Figure 4 Mean $\mathrm{Gl}_{50}$ graph demonstrating the selective nature of growth inhibition by $(\mathbf{A})$ compound $\mathbf{2}$ and $(\mathbf{B})$ compound $\mathbf{2 b}$ in the NCl in vitro panel of human derived cancer cell lines. Cells were exposed to drug for $48 \mathrm{~h}$ before viability was determined using the sulforhodamine B assay. Display of data utilises the mean graph format where the average $\mathrm{Gl}_{50}$ concentration is plotted on the centre line. Using a log scale, the sensitivity or resistance of a particular cell line is represented by deflections to the right or left, respectively, from the mean. 
Media levels of regenerated compound 1 reached a peak at day 3, thereafter declining as oxidative metabolism by MCF-7 and T47D sensitive cells yielded its inactive 6-hydroxy metabolite. In contrast,

Table I Retention of biological activity following conjugation of alany and |ysyl residues to 2-(4-amino-3-methylphenyl)benzothiazole compounds $\mathbf{I}, \mathbf{2}, \mathbf{3}$ and $\mathbf{4}$

\begin{tabular}{|c|c|c|c|c|}
\hline Compound & $\begin{array}{c}\mathrm{GI}_{50} \\
\mathrm{MCF-7} \\
(\mathrm{nM})\end{array}$ & $\begin{array}{c}\mathrm{GI}_{50} \\
\text { MDA } 468 \\
(\mathrm{nM})\end{array}$ & $\begin{array}{c}\text { Induction } \\
\text { EROD activity: } \\
\text { nM resorufin } \\
\mathrm{mg}^{-1} \text { protein }\end{array}$ & $\begin{array}{l}\text { Microsomal } \\
\text { CYPIAI } \\
\text { EROD activity } \\
\text { (\% control) }\end{array}$ \\
\hline I & $<0.1^{\mathrm{a}}$ & $<0.1^{a}$ & 17.58 & 22.58 \\
\hline Ia & 0.32 & 39.9 & nd & nd \\
\hline Ib & 41.6 & 67.1 & nd & nd \\
\hline 2 & $<0.1$ & $<0.1$ & 36.64 & 30.40 \\
\hline $2 a$ & 5.8 & 37.7 & 28.37 & 40.59 \\
\hline $2 b$ & 39.1 & 57.7 & 35.56 & $38.48^{\mathrm{b}}$ \\
\hline 3 & $0.65^{\mathrm{a}}$ & $0.73^{\mathrm{a}}$ & 32.60 & 36.38 \\
\hline $3 \mathbf{a}$ & 43.5 & 296.6 & 20.40 & 28.90 \\
\hline 3b & 147.1 & 328.0 & 19.88 & 46.97 \\
\hline 4 & $<0.1^{a}$ & $3.55^{\mathrm{a}}$ & 32.02 & 43.15 \\
\hline $4 a$ & 33.0 & 219.9 & 17.09 & 41.92 \\
\hline 4b & 30.7 & 301.7 & 20.04 & 54.94 \\
\hline
\end{tabular}

(I) Inhibition of ER+ MCF-7 and ER- MDA 468 human breast carcinoma cell growth. Cells were treated with compound for 3 days $(n=8)$ before viability was assessed by MTT assay. Experiments were performed three times and representative mean values shown. ${ }^{a}$ Signifies a biphasic dose response relationship. (2) Induction of EROD activity in lysates of MCF-7 cells treated with compounds (I $\mu \mathrm{M}, 24$ h). Negligible activity was detected in control, untreated cell lysates. Means of three experiments are shown, s.d. $<10 \%$. (3) Inhibition of recombinant CYPIA activity by $30 \mu \mathrm{m}$ agent. Incubates containing no drug represent $100 \%$ activity. Means of three experiments are shown, s.d. $<10 \%$. ${ }^{\text {b }}$ This data is represented graphically in Figure 5B. nd=experiments not performed.

A

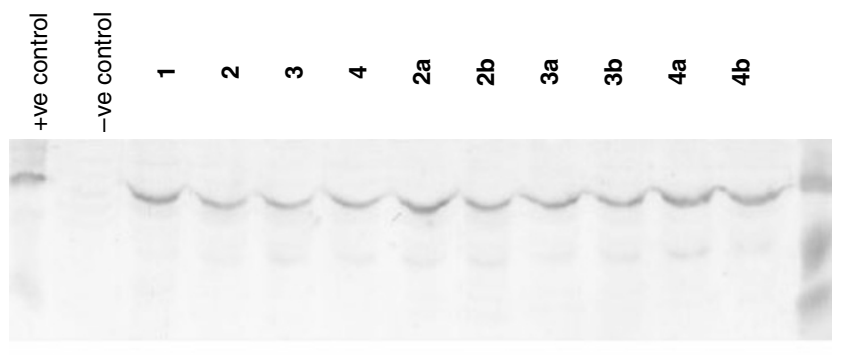

B

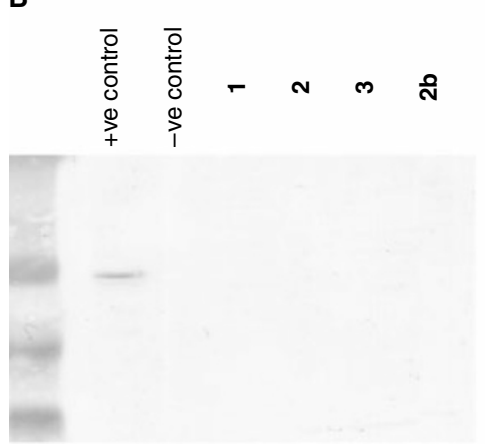

Figure 5 Western Blot detection of CYPIAI protein induced in lysates of (A) MCF-7 cells exposed to compounds I, $\mathbf{2}, \mathbf{3}, \mathbf{4}, \mathbf{2 a}, \mathbf{2} \mathbf{b}, \mathbf{3 a}, \mathbf{3} \mathbf{b}, \mathbf{4 a}$ and $\mathbf{4 b}(\mathrm{I} \mu \mathrm{M}, 24 \mathrm{~h})$. CYPIAI expression was not detected constitutively in lysates of untreated MCF-7 or (B) HCT II6 cells and not induced in HCT I I 6 cells exposed to compounds I, $\mathbf{2}, \mathbf{3}$ or $\mathbf{2 b}$. For each sample, $50 \mu \mathrm{g}$ total protein was loaded onto the gel. negligible net removal of effluxed compound $\mathbf{1}$ occurred from media supporting the growth of inherently resistant A498 cells, which fail to sequester and metabolise 2-(4-aminophenyl)benzothiazoles (Kashiyama et al, 1999). Thus, compound 1, regenerated from the amide prodrugs accumulated harmlessly in the media of A498 cells over the 7 day incubation period.

Amino acid prodrugs of compounds 2, 3 and 4 were stable in medium alone at $37^{\circ} \mathrm{C}>7$ days: detection of parent drug during this time was negligible. Uptake and metabolism of compounds 2a, 2b, 3a, 3b, 4a and $\mathbf{4 b}(10 \mu \mathrm{M})$ by MCF-7 cells were examined; conditions for HPLC analysis allowed detection of prodrug, parent compound and metabolites. All alanyl- and lysyl-amide prodrugs were rapidly depleted from nutrient media in the presence of cells and conversion of prodrugs to parent amines was apparent after $24 \mathrm{~h}$. Release of compound 2 into nutrient medium was significant after $24 \mathrm{~h}$ and continued to increase throughout the 7 day period.
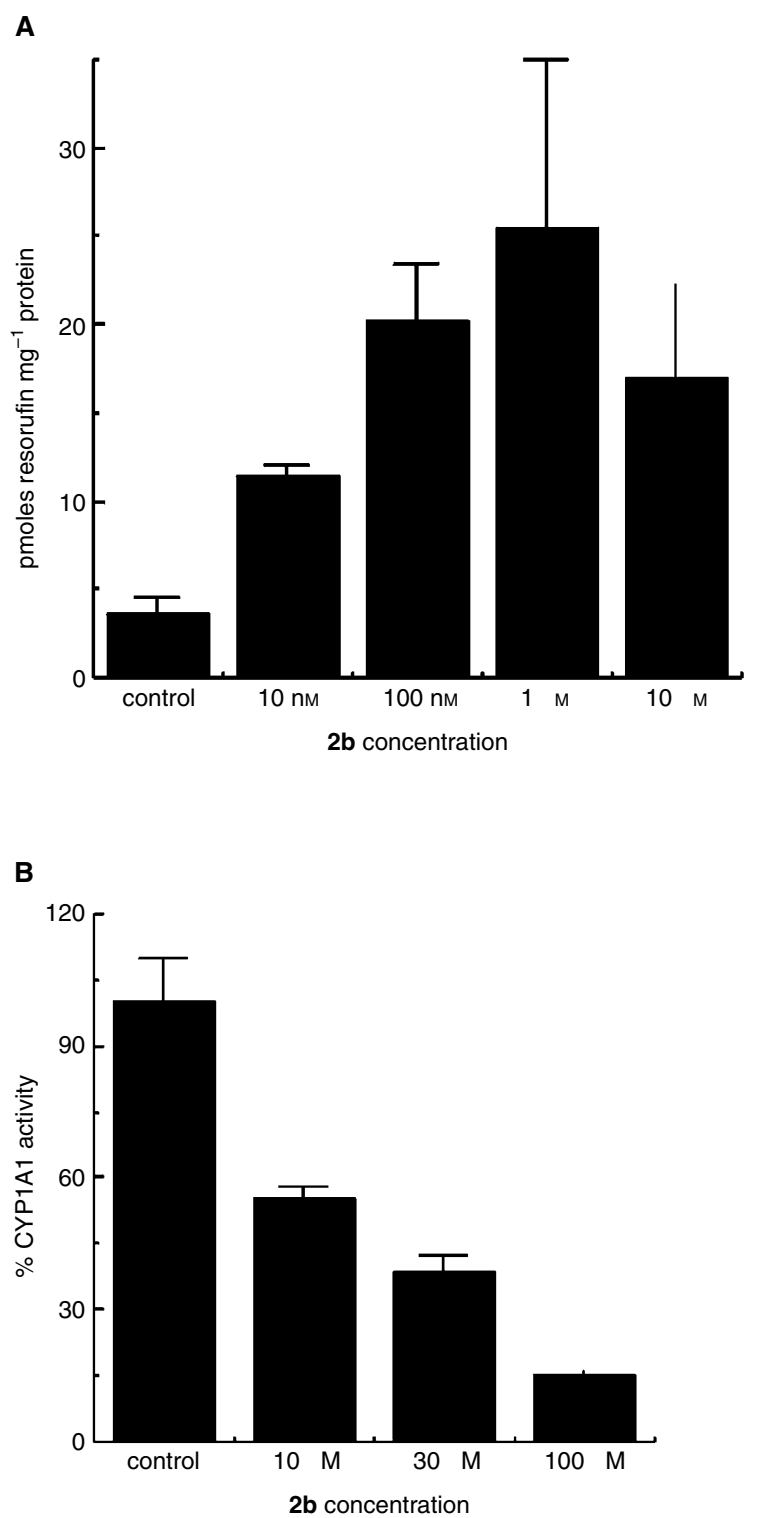

Figure 6 (A) EROD activity in homogenates of IGROV-I cells treated with concentrations of compound $\mathbf{2 b}$ for $24 \mathrm{~h}$. Mean values of three experiments are shown; bars, s.d. (B) Inhibition of CYPIAI microsomal EROD activity by compound $\mathbf{2 b}$. Resorufin product was measured after coincubation of CYPIAI microsomes with compount $\mathbf{2 b}$ for 15 min at $37^{\circ} \mathrm{C}$. Mean values of three experiments are shown; bars, s.d. 
No biotransformation products could be detected (Figure 3A). In contrast, emergence of an oxidative metabolite accompanied detection of compounds 3 and 4 (days 1-7, Figure 3B,C).

\section{In vitro cytotoxicity}

In the NCI panel of human-derived carcinoma cell lines, tested amino acid salts of compounds $\mathbf{1}, 2$ and 3 retained the selective growth inhibitory properties of their parent amines; mean graphs demonstrated activity against certain ovarian, renal and breast cell lines following standard $48 \mathrm{~h}$ exposure (e.g. Figure 4). However, as expected considering the prodrug nature of compound $\mathbf{2 b}$, following $48 \mathrm{~h}$ exposure, potency at the $\mathrm{GI}_{50}$ level in sensitive cell lines was reduced. Data obtained following examination of activity of amino acid salts of compounds 1, 2, 3 and 4 in MCF-7 and MDA 468 breast cancer cells corroborates this observation: typically, after $72 \mathrm{~h}$ exposure, $\mathrm{GI}_{50}$ values were two orders of magnitude greater than the parent amine (Table 1). However, neither alanyl nor lysyl prodrugs evoked the biphasic dose response characteristic of sensitive cell lines exposed to non-conjugated parent amines compounds 1,3 or 4 .

\section{Mechanism of action studies}

Figure 5 demonstrates selective induction of CYP1A1 protein expression in lysates of MCF-7 cells treated with benzothiazole prodrugs and their parent amines $(1 \mu \mathrm{M}, 24 \mathrm{~h})$. No CYP1A1 was detected in lysates of HCT 116 or untreated MCF-7 cells. In addition, expression of CYP1A1 protein was clearly observed in lysates of IGROV-1 cells after exposure to concentrations of compound $\mathbf{2 b}$ between $10 \mathrm{nM}$ and $10 \mu \mathrm{M}$ ( $24 \mathrm{~h}$, result not shown). Similarly, only lysates of sensitive cells exposed to prodrugs effected deethylation of ethoxyresorufin, indicative of CYP1A1 activity (Table 1). Figure $6 \mathrm{~A}$ demonstrates the biphasic dose response relationship between CYP1A1-catalysed conversion of ethoxyresorufin to resorufin and compound $\mathbf{2 b}$ concentration in lysates of IGROV-1 cells exposed to this agent for $24 \mathrm{~h}$. Maximum induction of EROD activity followed treatment of cells with $1 \mu \mathrm{M}$ compound $\mathbf{2 b}$. It has been speculated that these agents are metabolised by CYP1A1 to a reactive intermediate that covalently binds to, and then inactivates the enzyme; the activity of CYP1A1 microsomes was irreversibly inhibited by compound $\mathbf{1}$ (Chua et al, 2000). Indeed, significant inhibition of CYP1A1 microsomal EROD activity was monitored when incubates included compounds $\mathbf{1}, \mathbf{2}, \mathbf{2 a}, \mathbf{2} \mathbf{b}, \mathbf{3}, \mathbf{3 a}, \mathbf{3} \mathbf{b}, \mathbf{4}$, 4a, 4b (Table 1, Figure 6B).

\section{DISCUSSION}

Data have been presented describing the in vitro biological properties of alanyl and lysyl amide derivatives of 2-(4-amino-3methylphenyl)benzothiazoles. Prodrugs are rapidly depleted from nutrient media, generating their parent species in the presence of cells (Figures 2 and 3 ). In the absence of cells, no spontaneous hydrolysis of the amide bond occurs to release the amine from its amino acid salt. The cleavage of amino acid amides may be catalysed by ubiquitously expressed aminopeptidases, but subsequent bioactivating steps, essential for the mechanism of action of aminophenylbenzothiazoles, take place selectively in sensitive cell lines (e.g. Figure 5). Compounds $\mathbf{1 a}$ and $\mathbf{1 b}$ were stable when incubated at $37^{\circ} \mathrm{C}$ with human plasma; specifically, no free amine was detected. Amino acid amide stability, assessed in aqueous solution over a $\mathrm{pH}$ range of $4-9$, was found to be $\mathrm{pH}$ dependent with more acidic $\mathrm{pH}$ favouring greater stability (Hutchinson et al, 2002).

The selective depletion of amine (e.g. compound 1, Figure 2b) from nutrient media in vitro, and accumulation in sensitive cells only has been reported previously (Kashiyama et al, 1999; Chua et al, 2000).

The remarkably potent and selective antitumour activity characteristic of this class of agent is retained; total growth inhibition (TGI) and cytocidal effects $\left(\mathrm{LC}_{50}\right)$ were elicited by nM concentrations following amino acid conjugation coupled with monofluoro substitution. In vitro, prodrug compound $\mathbf{2 b}$ exhibits a superior antitumour profile. In vivo, plasma concentrations of compound $\mathbf{2}$, regenerated from lysylamide prodrug compound $\mathbf{2 b}$, sufficient to elicit cytocidal activity against human mammary carcinoma cells persist $>6 \mathrm{~h}$ (Bradshaw et al, 2002). Indeed, compound $2 \mathbf{b}$ suppresses significantly the growth of breast and ovarian xenografts in vivo.

Planar, hydrophobic 2-(4-aminophenyl)benzothiazoles fulfil structural requirements for binding to the aryl hydrocarbon receptor (AhR), and are potent AhR agonists (Loaiza-Perez et al, 2002). Subsequent induction of CYP1A1 mRNA (Hose et al, 2001; Monks et al, 2001) activity and protein expression (Chua et al, 2000; Hutchinson et al, 2001) only in cell lines sensitive to the growth inhibitory properties of 2-(4-amino-3-methylphenyl)benzothiazoles has been reported. That the role of CYP1A1 as a putative target for the mechanism of action of this class of compound was not compromised following prodrug modification of the 2-(4-aminophenyl)benzothiazole structure has been verified (Table 1, Figures 5 and 6). Induction of CYP1A1 protein expression and EROD activity in lysates of sensitive MCF-7 breast, IGROV-1 ovarian cells was observed following exposure to prodrugs. Lysates of insensitive HCT 116 cells treated with prodrugs neither expressed CYP1A1 protein nor effected ethoxyresorufin $O$-deethylation.

Induction of CYP1A1 activity and protein expression probably leads to generation of a reactive electrophilic species and benzothiazole-derived covalent binding to CYP1A1, resulting in enzyme inactivation (Chua et al, 2000). We have established that at prodrug compound $\mathbf{2 b}$ concentrations $>1 \mu \mathrm{M}$, EROD activity, induced in lysates of treated sensitive cells, begins to decline (Figure 6A). Moreover, $\mu \mathrm{M}$ prodrug concentrations inhibit microsomal CYP1A1 activity (Figure 6B), substantiating the thesis that these agents are inducers, substrates and suicide inhibitors of CYP1A1. Generation of a CYP1A1-dependent reactive electrophilic species preceeds detection of DNA adducts (Stevens et al, 2001), and ultimately cell death.

In conclusion, alanyl- and lysyl-amide prodrugs of 2-(4-amino3-methylphenyl)benzothiazoles undergo reversion to their parent amine. In vitro efficacy and selectivity are retained. Stark antitumour selectivity can be rationalised, and involvement of a crucial molecular target of this class of agent demonstrated. In addition, chemical stability and aqueous solubility is exhibited rendering these synthetically accessible prodrugs suitable for further preclinical development.

\section{ACKNOWLEDGEMENTS}

This study was supported by Cancer Research UK, and the National Cancer Institute. This is part 19 of the series 'Antitumour 2-(4-aminophenyl)benzothiazoles'. The authors thank Cancer Research UK, for support to the Cancer Research UK Experimental Cancer Chemotherapy Research Group, Nottingham. We also thank the University of Nottingham, UK, for a scholarship (to M-S Chua). We gratefully acknowledge extensive collaborations, support and discussions with the staff of the Developmental Therapeutics Program of the NCI and members of the Screening and Pharmacology Group within the European Organisation for Research and Treatment of Cancer (EORTC). 


\section{REFERENCES}

Boyd MR, Paull KD (1995) Some practical considerations and applications of the National Cancer Institute. in vitro anticancer drug discovery screen. Drug Development Res 34: $91-109$

Bradford MM (1976) A rapid and sensitive method for the quantitation of microgram quantities of protein utilizing the principle of protein-dye binding. Anal Biochem 72: $248-254$

Bradshaw TD, Wrigley S, Shi D-F, Schultz RJ, Paull KD, Stevens MFG (1998a) 2-(4-Aminophenyl)benzothiazoles: novel agents with selective profiles of in vitro antitumour activity. Br J Cancer 77: 745-752

Bradshaw TD, Shi D-F, Schultz RJ, Paull KD, Kelland L, Wilson A, Garner C, Fiebig HH, Wrigley S, Stevens MFG (1998b) Influence of 2-(4-aminophenyl)benzothiazoles on growth of human ovarian carcinoma cell lines in vitro and in vivo. Br J Cancer 78: $421-429$

Bradshaw TD, Bibby MC, Double JA, Fichtner I, Cooper PA, Alley MC, Donohue S, Stinson SF, Tomaszewjski JE, Sausville E, Stevens MFG (2002) Preclinical evaluation of amino acid prodrugs of novel 2-(4amino-3-methylphenyl)benzothiazoles. Mol Can Therapeutics 45: 239-246

Burke MD, Thompson S, Weaver RJ, Wolf CR, Mayer RT (1994) Cytochrome P450 specificities of alkoxyresorufin $O$-dealkylation in human and rat liver. Biochem Pharmacol 48: $923-936$

Chua M-S, Shi D-F, Wrigley S, Bradshaw TD, Hutchinson I, Shaw PN, Barrett DA, Stanley LA, Stevens MFG (1999) Antitumour benzothiazoles. 7. Synthesis of 2-(4-acylaminophenyl)benzothiazoles and investigations into the role of acetylation in the antitumour activities of the parent amines. J Med Chem 42: $381-392$

Chua M-S, Kashiyama E, Bradshaw TD, Stinson SF, Brantley E, Sausville EA, Stevens MFG (2000) Role of CYP1A1 in modulation of antitumour properties of the novel agent 2-(4-amino-3-methylphenyl)benzothiazole (DF 203, NSC 674495) in human breast cancer cells. Cancer Res 60: 5196-5203

Hose C, Riviera M, Sausville E, Monks A (2001) Induction of cytochrome P450 CYP1A1 and cytochrome P450 CYP1B1 by 2-(4-amino-3-methylphenyl)benzothiazole (BZ) in 60 human tumour cell lines: correlation with BZ toxicity. Proc Am Assoc Cancer Res 42(2749): 511
Hutchinson I, Chua M-S, Browne HL, Trapani V, Fichtner I, Bradshaw TD, Westwell AD, Stevens MFG (2001) Antitumour benzothiazoles. 14. The synthesis and unique antitumour properties of fluorinated 2-(4-aminophenyl)benzothiazoles. J Med Chem 44: 1446-1455

Hutchinson I, Jennings SA, Vishnuvajjala BR, Westwell AD, Stevens MFG (2002) Antitumour benzothiazoles. 16. Synthesis and pharmaceutical properties of antitumour 2-(4-aminophenyl)benzothiazole amino acid prodrugs. J Med Chem 45: $744-747$

Kashiyama E, Hutchinson I, Chua M-S, Stinson SF, Phillips LR, Kaur G, Sausville EA, Bradshaw TD, Westwell AD, Stevens MFG (1999) Antitumour benzothiazoles. 8. Synthesis, metabolic formation, and biological properties of the $C$ - and $N$-oxidation products of antitumour 2-(4-aminophenyl)benzothiazoles. J Med Chem 42: 4172-4184

Loaiza-Pérez AI, Trapani V, Hose C, Singh SS, Trepel J, Stevens MFG, Bradshaw TD, Sausville EA (2002) The AhR mediates sensitivity of MCF-7 breast cancer cells to the antitumour agent 2-(4-amino-3-methylphenyl)benzothiazole. Mol Pharmacol 61: 13-19

Monks A, Rivera MI, Harris E, Hose C, Sausville EA (2001) Gene expression changes induced by a novel antitumour agent, 2-(4-amino-3-methylphenyl)benzothiazole, in MCF-7, a sensitive breast cancer cell line, using cDNA microarrays. Proc Am Assoc Cancer Res 42(3417): 635

Pochopin NL, Charman WN, Stella VY (1995) Amino acid derivatives of dapsone as water soluble prodrugs. Int J Pharmaceutics 121: $157-167$

Shi D-F, Bradshaw TD, Wrigley S, McCall CJ, Lelieveld P, Fichtner I, Stevens MFG (1996) Antitumour benzothiazoles. 3. Synthesis of 2-(4-aminophenyl)benzothiazoles and evaluation of their activities against breast cancer cell lines in vitro and in vivo. J Med Chem 39: 3375-3384

Stevens MFG, Heydon RT, Martin EA, Farmer PB, Bradshaw TD, Hutchinson I, Westwell AD, Browne HL, Trapani V (2001) Induction of CYP1A1 by 2-(4-aminophenyl)benzothiazoles leads to DNA adducts in sensitive tumour cells. Proc Am Assoc Cancer Res 42(1754): 325 